\title{
Importance of the so-called 'other' sexually-transmitted diseases
}

\author{
R. R. WILLCOX* \\ St. Mary's Hospital, London W.2, and King Edward VII Hospital, Windsor, England
}

\section{Scope of problem}

There are numerous sexually-transmitted diseases other than syphilis and gonorrhoea caused by bacteria, Chlamydia, viruses, protozoa, fungi, and parasites (Table-see Willcox, 1972). In addition, excluding viruses like that of glandular fever which may be transmitted by kissing, there are numerous other sexually-transferable organisms which are known or suspected to be responsible for significant pathology. These include Haemophilus vaginalis, $\beta$ streptococcus, mycoplasmas, cytomegalovirus and the virus of hepatitis $B$, and on occasion protozoa such as $E$. histolytica and helminths such as Enterobius vermicularis may also be passed in this way.

TABLE Sexually-transmitted diseases

\begin{tabular}{|c|c|c|}
\hline \multicolumn{2}{|l|}{ Organism } & \multirow{2}{*}{$\frac{\text { Disease }}{\text { Syphilis }}$} \\
\hline Spirochaetes & $T$. pallidum & \\
\hline Bacteria & $\begin{array}{l}\text { Gonococcus } \\
\text { H. ducreyi } \\
\text { D. granulomatis }\end{array}$ & $\begin{array}{l}\text { Gonorrhoea } \\
\text { Chancroid } \\
\text { Granuloma inguinale }\end{array}$ \\
\hline Chlamydia & $\begin{array}{l}\text { LGV agent } \\
\text { TRIC agent }\end{array}$ & $\begin{array}{l}\text { Lymphogranuloma } \\
\text { venereum } \\
\text { Non-gonococcal urethritis }\end{array}$ \\
\hline Viruses & $\begin{array}{l}\text { Type } 2 \text { herpes virus } \\
\text { Other viruses }\end{array}$ & $\begin{array}{l}\text { Herpes genitalis } \\
\text { Condylomata acuminata } \\
\text { Molluscum contagiosum }\end{array}$ \\
\hline Protozoa & $T$. vaginalis & Trichomoniasis \\
\hline Fungi & $\begin{array}{l}\text { Candida albicans } \\
\text { Torulopsis glabrata }\end{array}$ & Thrush \\
\hline Parasites & $\begin{array}{l}\text { Acarus scabei } \\
\text { Phthirus pubis }\end{array}$ & $\begin{array}{l}\text { Scabies } \\
\text { Pediculosis pubis }\end{array}$ \\
\hline
\end{tabular}

\section{Incidence}

In many developed countries several of the conditions listed have an incidence exceeding, sometimes by

Received for publication November 22, 1974

*Member WHO Expert Advisory Panel on Venereal Infections and Treponematoses

Paper presented to WHO Meeting on Health Education in the Control of Sexually-transmitted Diseases, Geneva, November 11-15, 1974 many times, that of primary and secondary syphilis or even that of gonorrhoea, but relatively few figures are available. Those provided by the venereal disease clinics of England and Wales in 1973 are presented in Annex I, which also includes particulars of primary and secondary syphilis and of gonorrhoea. It is noted that the first five conditions, in the order most commonly encountered in males, were nonspecific genital infection, post-pubertal gonorrhoea, condylomata acuminata, candidiasis, and herpes genitalis-and in females the first five were candidiasis, post-pubertal gonorrhoea, trichomoniasis, nonspecific genital infection, and condylomata acuminata. Only the figures for candidiasis and trichomoniasis in the female exceed those of the male.

ANNEX I Sexually-transmitted diseases in England and Wales, 1971-1973

\begin{tabular}{|c|c|c|c|c|}
\hline \multirow[b]{2}{*}{ Disease } & \multicolumn{2}{|l|}{ Males } & \multicolumn{2}{|c|}{ Females } \\
\hline & 1973 & $\begin{array}{l}\text { Per cent. } \\
\text { change } \\
\text { since } 1971\end{array}$ & 1973 & $\begin{array}{l}\text { Per cent. } \\
\text { change } \\
\text { since } 1971\end{array}$ \\
\hline \multicolumn{4}{|l|}{ Non-specific genital } & +10.9 \\
\hline \multicolumn{5}{|l|}{ Post-pubertal } \\
\hline Condylomata acuminata & 11,922 & $+30 \cdot 7$ & 6,449 & $+31 \cdot 5$ \\
\hline Candidiasis & 5,058 & $+67 \cdot 8$ & 27,545 & $+25 \cdot 5$ \\
\hline Herpes simplex & 3,419 & $+21 \cdot 5$ & 1,567 & $+67 \cdot 1$ \\
\hline Pediculosis pubis & 3,263 & $+2 \cdot 8$ & 1,143 & $+13 \cdot 5$ \\
\hline Scabies & 2,167 & $-17 \cdot 3$ & 465 & $-39 \cdot 1$ \\
\hline Trichomoniasis & 1,643 & $+18 \cdot 5$ & 18,032 & $+1 \cdot 1$ \\
\hline \multicolumn{5}{|l|}{ Primary and secondary } \\
\hline Molluscum contagiosum & 490 & $+29 \cdot 6$ & 180 & $+25 \cdot 0$ \\
\hline venereum & 60 & $+33 \cdot 3$ & 8 & figures \\
\hline Chancroid & 34 & $-32 \cdot 0$ & 2 & too \\
\hline Granuloma inguinale & 5 & nil & 3 & small \\
\hline
\end{tabular}

(Courtesy of the Department of Health and Social Security)

It is also shown that, between 1971 and 1973, increases of 20 per cent. or more have occurred in the incidence of candidiasis, primary and secondary syphilis, lymphogranuloma venereum, condylomata acuminata, molluscum contagiosum, and herpes simplex in declining order in males, and of herpes 
simplex, condylomata acuminata, candidiasis, and molluscum contagiosum in females.

The object of this paper is to indicate that the morbidity of sexually-acquired diseases other than syphilis and gonorrhoea, in terms of potential disability and even death, is likewise not inconsiderable. Where figures are available from the clinics of England and Wales they are compared with those for syphilis and post-pubertal gonorrhoea.

\section{Diseases caused by bacteria}

\section{CHANCROID}

Caused by $H$. ducreyi, soft sore had at one time a world-wide high prevalence, but it has now become rare in developed countries (primary and secondary syphilis in 1973 was 43 times more common and gonorrhoea 1,671 times more common in the venereal disease clinics of England and Wales). It nevertheless remains a significant problem in many areas, e.g. parts of Africa and the Far East, and in Vietnam resistance has arisen to treatment with sulphonamides and tetracyclines (Marmar, 1972). In severe cases, with associated phagedena, much tissue destruction may result. A recrudescence of chancroid in parts of Europe, e.g. France, has recently been reported (Colomb, Brunet, and Valignat, 1971; Perrot, Beyuin, and Étienne, 1971).

\section{GRANULOMA INGUINALE}

Caused by Donovania granulomatis-a Gram-negative bacterium, donovanosis is usually rare; it is more common in the tropics and subtropics but is occasionally encountered in Europe (in the clinics of England and Wales in 1973 primary and secondary syphilis was 194 times and gonorrhoea no less than 7,521 times more common). The condition is endemic in the southern States of India, especially along the Eastern seaboard (Rajam and Rangiah, 1954), and is prevalent to a remarkable degree in Papua New Guinea (Maddocks, 1967) where in 1973 in the Central (Port Moresby) District the reported cases were $\mathbf{8 2}$ times more numerous than those of primary and secondary syphilis and only 2.6 times less than those of gonorrhoea (Willcox, 1974).

Remote lesions in skin and bone may be encountered and there is an apparent relationship between granuloma inguinale and cancer of the vulva and penis (Stewart, 1964; Goldberg and Annamunthodo, 1966).

\section{HAEMOPHILUS VAGINALIS}

This bacterium, the significance of which is still unclear, is frequently isolated from the female genital tract (Dunkelberg, Skaggs, Kellogg, and Domescik,
1970) and is found in a significant number of patients with vaginitis (Lewis, O'Brien, Ural, and Burke, 1971). No data are available as to incidence, but in 1973 in England and Wales, excluding those cases due to trichomoniasis and thrush, there were 68 times more cases of non-specific genital infection in females than of primary and secondary syphilis, and gonorrhoea in females was only 1.4 times more common: the proportion in which $H$. vaginalis may have been involved is unknown.

The organism, which has been considered a possible cause of non-specific urethritis in the male (Furness, Kamat, Kaminski, and Seebode, 1971), can be responsible for maternal and neonatal septicaemia (Carney, 1973) and sepsis (Platt, 1971).

\section{MYCOPLASMAS}

For some years these organisms have been incriminated as a possible or likely cause of the bulk of cases of non-gonococcal urethritis, especially the T-strain (Shepard, 1956). While undoubtedly sexually transmitted-attachment to sperms has been demonstrated (Gnarpe and Friberg, 1972)-their prime position in this respect has now been assumed by Chlamydia (q.v.).

Mycoplasmas have been found in cases of salpingitis and genital infections in the female (Mårdh and Weström, 1970) and some authors (e.g. Foy, Kenny, Wentworth, Johnson, and Grayson, 1970; Kundsin and Driscoll, 1970; Harwick, Purcell, Iuppa, and Fekety, 1971; Caspi, Solomon, and Sompolinsky, 1972; Soldatova, Bashmakova, and Stepanova, 1972; Di Musto, Bohjalian, and Millar, 1973) have pointed to an association between the presence of both $M$. hominis and $\mathrm{T}$-strains with high-risk pregnancies including such pathology as abortion, stillbirth, prematurity, low birth weight, and puerperal infection.

\section{OTHER BACTERIA}

Cases of arthritis apparently due to Mimea have been recorded by Kozub, Bucolo, Sami, Chatman, and Pribor (1968) and by Feigin, San Joaquin, and Middlekamp (1969) and one of ophthalmia neonatorum was described by Sood and Madhaven (1968). The $\beta$ streptococcus has likewise been incriminated as a cause of neonatal sepsis.

\section{Diseases caused by Chlamydia}

\section{LYMPHOGRANULOMA VENEREUM}

This condition is widely distributed but is generally uncommon. It is endemic in the South American ports, the West Indies, and the West African coast and Madagascar, but seems to be a dying disease (Duhamel and Cohen, 1970). In the clinics of England and Wales in 1973, it was 23 times less common than 
syphilis and 885 times less common than gonorrhoea.

It may be responsible for genital ulceration, elephantiasis, polypoid growths, proctitis, and perirectal abscesses in both sexes, and in the female particularly for rectovaginal fistulae, tissue loss with disabling urinary and rectal incontinence, and rectal strictures (Lawson, 1963; Weinstein, Hayashida, and Clark, 1966).

\section{NON-GONOCOCCAL URETHRITIS}

This extremely widespread condition is more common than gonorrhoea in males in many areas, and even where its incidence is reported many cases in which it follows treated gonorrhoea are not statistically noted. In the clinics of England and Wales the numbers increased more than three-fold between 1951-1970 (Annex II) and in 1973 non-specific genital infections in males were 53 times more common than primary and secondary syphilis and 1.8 times more common than post-pubertal gonorrhoea in men.

Chlamydia (TRIC agent) have been isolated from about 40 per cent. of cases (Dunlop, VaughanJackson, Darougar, and Jones, 1972; Oriel, Reeve, Powis, Miller, and Nicol, 1972a ; Richmond, Hilton, and Clarke, 1972). This agent has been found in material from the cervix of partners of infected men and may also be responsible for a form of ophthalmia neonatorum (Jones, 1972). The possibility of a genital reservoir for trachoma has been suggested (see Jones, 1972; Al-Hussaini, Wasfy, Shokeir, Shaaban, and Khaleil, 1970; Shaaban, Shokeir, Wasfy, and Al-Hussaini, 1972). Chlamydia have also been incriminated as a cause of pelvic inflammatory disease (Mordhorst and Dawson, 1971).

One of the distressing complications of nongonococcal urethritis is that of Reiter's syndrome which may result in acute, subacute, and/or chronic arthritis, recurrent uveitis, and occasionally aortic valvular defects with cardiac invalidism (Csonka, Litchfield, Oates, and Willcox, 1961).

In the 8 years $1963-1970$, some 266,258 cases of non-gonococcal urethritis were treated in the clinics of England and Wales and there were also 2,675 additional patients with arthritis ( 1 per cent. of the total)-see Annex II. This would seem to support the thesis that only certain persons are susceptible to Reiter's syndrome should they be exposed to infection and that this predisposition may have a genetic basis (Lawrence, 1974).

\section{Diseases caused by viruses}

HERPES GENITALIS

In the clinics of England and Wales in 1973 infections with genital herpes simplex were 2.6 times more common than those with primary and secondary syphilis in males and 7.1 times more common in
ANNEX II Incidence of arthritis and non-gonococcal urethritis (England and Wales)*

\begin{tabular}{|c|c|c|c|}
\hline \multirow[b]{2}{*}{ Year } & \multirow[b]{2}{*}{$\begin{array}{l}\text { Non-gonococcal } \\
\text { urethritis }\end{array}$} & \multicolumn{2}{|c|}{ NGU with arthritis } \\
\hline & & No. & $\begin{array}{l}\text { As percentage of } \\
\text { cases without } \\
\text { arthritis }\end{array}$ \\
\hline $\begin{array}{l}1951 \\
1963 \\
1964 \\
1965 \\
1966 \\
1967 \\
1968 \\
1969 \\
1970\end{array}$ & $\begin{array}{l}14,975 \\
25,001 \\
27,166 \\
28,846 \\
30,135 \\
31,961 \\
35,423 \\
40,814 \\
46,912\end{array}$ & $\begin{array}{l}\text { NR } \\
288 \\
355 \\
295 \\
327 \\
357 \\
298 \\
375 \\
380\end{array}$ & $\begin{array}{l}\text { NR } \\
1.15 \\
1.31 \\
1.02 \\
1.09 \\
1.12 \\
0.84 \\
0.92 \\
0.81\end{array}$ \\
\hline Total & 266,258 & 2,675 & $1 \cdot 01$ \\
\hline
\end{tabular}

^Figures by courtesy of Dr. J. H. Berrie

females; the condition was 11.4 times less common than gonorrhoea in males and 13.6 times less common in females. The primary infection may affect the cervix without external signs (Willcox, 1968).

The sexually-transmitted Type 2 herpes virus has a highly significant potential morbidity. Apart from the occasional systemic infections with meningoencephalitis in adults (Illis and Merry, 1972; Craig and Nahmias, 1973), it may result in abortion if the mother is infected early (Nahmias, Josey, Naib, Freeman, Fernandez, and Wheeler, 1971) or in generalized, often fatal, infection in the newborn if she contracts the disease late in pregnancy (Hudson and McFarland, 1969; Pettay, Leinikki, Donner, and Lapinleimu, 1972). Involvement in the infant may include encephalitis (Hare, 1974).

After infection the virus persists and there is a strong association between antibodies in the blood and cancer of the cervix (Nahmias, Josey, Naib, Luce, and Guest, 1970; Rawls, Gardner, and Kaufman, 1970; Royston and Aurelian, 1970).

If herpes virus is truly the cause of cervical cancer, it carries an ultimate mortality considerably greater than that of syphilis and gonorrhoea combined-seven times that of syphilis in both sexes under present-day conditions in the eleven countries listed in Annex III and no less than 1,517 times that of gonorrhoea. As 1,567 infections were recorded in the female in the clinics of England and Wales in 1973 and 2,343 deaths from cervical cancer in the country as a whole, it is evident that, if this thesis is correct, the great majority of cases are seen outside the venereal disease clinics, or are not recognized.

Herpes virus has also been isolated from the urethra, prostate, or testicle in 15 per cent. of males attending a urology clinic who had no history of the disease (Centifanto, Drylie, Deardourff, and Kaufman, 1972). It was concluded that the relationship of herpes virus Type 2 to cancer of the male urogenital 
tract would warrant further study (in the countries listed in Annex III the mortality from prostatic cancer was 2.3 times that of the already considerable mortality from cervical cancer).

ANNEX III Deaths in 1970 in eleven countries ${ }^{*}$ from cervical cancer and from syphilis and gonorrhoea in both sexes (WHO, 1973)

\begin{tabular}{|c|c|c|c|}
\hline \multirow{2}{*}{ Country } & \multicolumn{3}{|l|}{ Deaths } \\
\hline & Cervical cancer & Syphilis & Gonorrhoea \\
\hline $\begin{array}{l}\text { USA } \\
\text { West Germany } \\
\text { England and Wales } \\
\text { Japan } \\
\text { France } \\
\text { Yugoslavia } \\
\text { Poland } \\
\text { Canada } \\
\text { Italy } \\
\text { Portugal } \\
\text { Czechoslovakia }\end{array}$ & $\begin{array}{r}6,940 \\
2,763 \\
2,343 \\
1,465 \\
925 \\
743 \\
699 \\
659 \\
595 \\
553 \\
518\end{array}$ & $\begin{array}{r}543 \\
309 \\
193 \\
660 \\
159 \\
104 \\
153 \\
40 \\
275 \\
89 \\
71\end{array}$ & $\begin{array}{l}3 \\
2 \\
2 \\
1 \\
2 \\
= \\
2 \\
= \\
-\end{array}$ \\
\hline Total deaths & 18,203 & 2,596 & 12 \\
\hline
\end{tabular}

*Chosen as having reported more than $\mathbf{5 0 0}$ deaths from cervical cancer (Deaths from prostatic cancer in the same year amounted to 41,035)

\section{CONDYLOMATA ACUMINATA}

This virus-induced disease is increasing in prevalence. In the clinics of England and Wales in 1973 condylomata were twelve times more common than primary and secondary syphilis and only 3.3 times less common than gonorrhoea.

Although generally not thought to be serious, giant lesions may occur and occasional malignancy has been reported (Rhatigan, Jimenez, and Chopskie, 1972). In addition, systemic toxicity (Chamberlain, Reynolds, and Yeoman, 1972) or severe haemorrhage (Young, Acosta, and Kaufman, 1973) has followed their treatment in some cases. The condition may be passed from mother to infant (Patel and Groff, 1972) and has been considered to be the cause of laryngeal papillomata in young children. An association of genital warts and cytomegalovirus has also been noted (Morse, Coleman, and Gardner, 1974).

\section{MOLLUSCUM CONTAGIOSUM}

This condition is also transmitted sexually (Cobbold and McDonald, 1970). It does not seem to result in any particular complications. In the clinics of England and Wales in 1973 the reported cases of molluscum contagiosum were exceeded 2.3 times by those of secondary syphilis and ninety times by those of post-pubertal gonorrhoea.

\section{CYTOMEGALIC INCLUSION DISEASE}

Cytomegalovirus is responsible for a glandular fever-like illness in adults but, when rarely transmitted through the placenta to the foetus, results in cytomegalic inclusion disease with hepatosplenomegaly, jaundice, choroido-retinitis, and central nervous system damage. Recovery is rare and tends to be associated with microcephaly, neurological dysfunction, and mental deterioration.

The virus has been found in from 0 to 3.6 per cent. of women undergoing routine examination (Jordan, Rousseau, Noble, Stewart, and Chin, 1973; Foy and others, 1970) and in 8.6 to 13.6 per cent. of women attending venereal disease clinics (Morse and others, 1974, at St. Mary's Hospital; Jordan and others, 1973); a higher figure of 23 per cent. of 385 cervical specimens from 100 venereal disease patients was reported by Wentworth, Bonin, Holmes, Gutman, Wiesner, and Alexander (1973). Further support for sexual transmission was provided by Lang and Kummer (1972) who found the virus in the semen of a man after a glandular fever-like illness which persisted for several weeks.

\section{HEPATITIS B}

There is some evidence that this condition, once called serum hepatitis, which can have considerable morbidity and is sometimes fatal, may be transmitted sexually, especially amongst homosexuals; this may well be the predominant means by which this virus is now maintained in the community, parental transmission being now only incidental (Fulford, Dane, Catterall, Woof, and Denning, 1973). Jeffries, James, Jefferiss, Macleod, and Willcox (1973) reported that 1.39 per cent. of 1,650 patients attending the venereal disease clinic at St. Mary's Hospital, London, carried the Australian antigen; this was more than ten times the incidence in the blood donor population, and amongst male homosexuals the rate was 3.8 per cent. Fulford and others (1973), testing 974 patients in another venereal disease clinic in the same city, found Australian antigen in 1.7 per cent. and antibody in 4.8 per cent. The antigen was detected in small quantity in the saliva and semen of patients who were serum carriers by Heathcote, Cameron, and Dane (1974), but there is at present no method of ascertaining whether such trace amounts are infective.

\section{Diseases caused by protozoa}

\section{TRICHOMONIASIS}

$T$. vaginalis is ubiquitous and is extremely common in venereal disease patients. In females in the clinics of England and Wales it was $12 \cdot 7$ times more common than primary and secondary syphilis in both sexes (82 times in the female) and only 1.2 times less common than gonorrhoea in the female. Although responsible for some cases of non-gonococcal urethritis in the male, its reported complications in both sexes are few in view of the vast numbers of persons involved. These, however, occasionally include 
adnexitis and pyosalpinx (Sebek, 1972), haematospermia, and epididymitis (Rasul, 1970), and it has been considered to have a possible role in infertility in both sexes (Nicora and Giarola, 1968; Walther, 1973) and also even in cancer (Bertini and Hornstein, 1969).

\section{OTHER PROTOZOAL DISEASES}

Entamoeba histolytica has been reported as occasionally responsible for extensive penile ulceration in Papua New Guinea (Mylius, 1974), the infection being presumed to have been contracted sexually. The amoeba has also been found in the female genital tract by Heinz (1973) in South Africa.

\section{Diseases caused by fungi}

\section{CANDIDIASIS}

Infections usually due to $C$. albicans or Torulopsis glabrata were responsible for 125 times the number of infections with primary and secondary syphilis and 1.3 times those of post-pubertal gonorrhoea in females in the clinics of England and Wales in 1973. Having a high nuisance value, the condition is increasing in prevalence (Nielsen, 1973), possibly because of the increased use of oral contraceptives (Oriel, Partridge, Denny, and Coleman, 1972b). Disease in the female appears to be related to host factors responsible for the proliferation of the organism rather than to the actual introduction of the fungus. Complications such as cystitis (Wise, Weinstein, Goldberg, and Kozinn, 1973) and endometritis (Rodriguez, Okagaki, and Richart, 1972) have been reported, as has azoospermia (Aubert and Arroyo, 1972).

\section{OTHER FUNGUS DISEASES}

Epidermophyton inguinale, the usual cause of tinea cruris, must also sometimes be transmitted sexually. Blastomycosis acquired in this way has been described by Farber, Leahy, and Meadows (1968).

\section{Diseases caused by parasites}

\section{SCABIES}

A survey by Orkin (1971) of 86 American and 73 other dermatologists indicated that scabies, uncommon in the 1950 s, had since shown a progressive increase in many parts of the world, for which Maleville and Heid (1972) blamed mass movement, economic depression, and promiscuity. In the clinics of England and Wales in 1973, it was 1.7 times more common than primary and secondary syphilis and 23 times less common than gonorrhoea.

The disease has acquired new bizarre forms through the inappropriate application of steroid ointments (Macmillan, 1972) and so-called 'Norwegian' scabies may also arise during immunosuppressive therapy (Paterson, Allen and Beveridge,
1973). In some parts of the world, e.g. Morocco, nephritis is a common complication following secondary infection (Rollier, 1969).

\section{PEDICULOSIS PUBIS}

In the clinics of England and Wales in 1973 pediculosis pubis was 2.8 times more common than primary and secondary syphilis and 13.7 times less common than gonorrhoea.

\section{OTHER PARASITIC DISEASES}

Cases of infestation by the threadworm (Enterobius vermicularis) have been reported in homosexuals indulging in penile-rectal and oro-genital contact by Waugh (1972) and by Harris and Morton (1973).

\section{Summary and conclusions}

(1) Some data are presented concerning the frequency and potential morbidity of sexuallytransmitted organisms other than $T$. pallidum or N. gonorrhoeae.

(2) Most of the diseases with which these organisms are associated are more prevalent than syphilis and some, at least in one sex, are as common as gonorrhoea. A number appear to carry considerable morbidity, which in the case of Type II herpes virus-if it is responsible for cervical cancer-may ultimately cause many more fatalities than syphilis.

(3) It is concluded: (a) that, if syphilis and gonorrhoea were reduced to the point of representing no public health concern, many other sexuallytransmitted conditions would still remain to pose significant problems: and $(b)$ that health education and other methods of prevention should, where possible, be designed to take into consideration the epidemiological implications of the other organisms listed.

\section{References}

AL-HussainI, M. K., Wasfy, I. A., Shokier, A. A., ShaAban, M. M. H., and Khaleil, A. A. H. (1970) Bull. ophthal. Soc. Egypt, 63, 75

AuBert, L., and Arroyo, H. (1972) Nouv. Presse méd., 1,2622

BerTINI, B., and HoRnstein, M. (1969) Harefuah, 77, 459

CARNEY, F. E. (1973) Obstet. and Gynec., 41, 78

CASPI, E., Solomon, F., and SOMPOLINSKY, D. (1972) Israel F. med. Sci., 8, 122

Centifanto, Y. M., Drylie, D. M., DeardourfF, S. L., and Kaufman, H. E. (1972) Science, 178, 318

Chamberlain, M. J., Reynolds, A. L., and Yeoman, W. B. (1972) Brit. med. F., 3, 391

Cobbold, R. J. C., and MacDonald, A. (1970) Practitioner, 204, 416

Colomb, D., Brunet, C., and Valignat, P. (1971) Lyon méd., 225, 647

Craig, C. P., and Nahmias, A. J. (1973) f. infect. Dis., 127, 365

CSONKA, G. W., Litchireld, J. W., OATes, J. K., and WILlcox, R. R. (1961) Brit. med. F., 1, 243 
Di Musto, J. C., Bohjalian, O., and Millar, M. (1973) Obstet. and Gynec., 41, 33

Duhamel, J., and Cohen, M. (1970) Arch. Mal. Appar. dig., 59, Suppl. 7-8, p.55

Dunkelberg, W. E., SkAgGs, R., Kellogg, D. S., and DoMEscIK, G. K. (1970) Brit. F. vener. Dis., 46, 187

Dunlop, E. M. C., Vaughan-Jackson, J. D., Darougar, S., and JoNES, B. R. (1972) Ibid., 48, 425

FARBER, E. R., LEAHY, M. S., and MEADOWS, T. R. (1968) Obstet. and Gynec., 32, 195

Feigin, R. D., San Joaquin, V., and Middlekamp, J. N. (1969) F. Pediat., 75, 116

Foy, H. M., KeNNY, G. E., WeNTWORTH, B. B., Johnson, W. J., and Grayson, J. T. (1970) Amer. F. Obstet., 76, 763

Fulford, K. W. M., Dane, D. S., Catterall, R. D., Woof, R., and DenNing, J. V. (1973) Lancet, 1, 1470

FURNESS, G., KAMAT, M. H., KAMINSKI, Z., and SEEBODE, J. J. (1971) F. Urol. (Baltimore), 106, 557

GNARPE, H., and Friberg, J. (1972) Amer. F. Obstet. Gynec., 114, 727, 963

Goldberg, J., and AnNAMunthodo, H. (1966) Brit. $\mathcal{F}$. vener. Dis., 42, 205

Hare, M. J. (1974) Proc. roy. Soc. Med., 67, 15

HARRIS, J. R. W., and MORTON, R. J. (1973) Brit. f. vener. Dis., 49, 393 (letter)

HaRwick, H. J., PURCell, R. H., IUPPa, J. B., and FEkETY, F. R. (1971) Obstet. and Gynec., 37, 767

Heathcote, J., Cameron, C. H., and Dane, D. S. (1974) Lancet, 1, 71

HeInz, K. P. W. (1973) S. Afr. med. F., 47, 1795

Hudson, A. W., and McFarLand, C. (1969) f. Amer. med. Ass., 208, 859

Illis, L. S., and MerRY, R. T. G. (1972) f. roy. Coll. Physcns (Lond.), 7, 34

Jefrries, D. G., James, W. H., JefFeriss, F. J. G., MACleod, K. G., and Willcox, R. R. (1973) Brit. med. F., 2, 455

JONES, B. R. (1972) Brit. F. vener. Dis., 48, 13

Jordan, M. C., Rousseau, W. E., Noble, G. R., Stewart, J. A., and CHIN, T. D. Y. (1973) New Engl. F. Med., 288, 932

Kozub, W. R., Bucolo, S., Sami, A. W., Chatman, C. E., and PrIBOR, H. C. (1968) Arch. intern. Med., 122, 514

Kundsin, R. B., and DRIscoll, S. G. (1970) Surg. Gynec. Obstet., 131, 89

LANG, D. J., and Kummer, J. F. (1972) New Engl.f. Med., 287, 756

LAWRENCE, J. S. (1974) Brit. F. vener. Dis., 50, 140

Lawson, J. B. (1963) West Afr. med. F., 12, 89

LEWIS, J. F., O'BRIEN, S. M., URAL, U. M., and BURKE, T. (1971) Amer. F. clin. Path., 56, 580

Macmillan, A. L. (1972) Brit. F. Derm., 87, 496

Maddocks, I. (1967) Papua New Guinea med. F., 10, 49

Maleville, J., and HeId, E. (1972) Munch. med. Wschr., 114, 27

MÁrDh, P. H., and Weström, L. (1970) Acta path. microbiol. scand., 78, Sect. B., 367

MARMAR, J. L. (1972) f. Urol. (Baltimore), 107, 807

Mordhorst, C. H., and Dawson, C. (1971) Amer. F. Ophthal., 71, 861

Morse, A. R., Colmman, D. V., and Gardner, S. D. (1974) f. Obstet. Gynaec. Brit. Cwlth, 81, 393

Mylrus, R. (1974) Personal communication.
Nahmias, A. J., Josey, W. E., NaIB, Z. M., Luce, C. F., and Guest, B. A. (1970) Amer. F. Epidem., v.91, 547-552

- —, - , Naib, Z. M., Freeman, M. G., Fernandez, R. J., and WHEELER, J. H. (1971) Amer. f. Obstet. Gynec., 110, 825

NicorA, G., and Giarola, A. (1968) Gynéc. prat., 19, 309

NirLSEN, R. (1973) Brit. F. vener. Dis., 49, 531

Oriel, J. D., Partridge, B. M., Denny, M. J., and Coleman, J. C. (1972b) Brit. med. F., 4, 761

-, Reeve, P., Powis, P., Miller, A. and Nicol, C. S. (1972a) Brit. F. vener. Dis., 48, 429

Orkin, M. (1971) f. Amer. med. Ass., 217, 593

Patel, R., and Groff, D. B. (1972) Pediatrics, 50, 152

Paterson, W. D., Allen, B. R., and Beveridge, G. W. (1973) Brit. med. F., 4, 211

Perrot, H., Beyuin, A. J., and Etienne, R. (1971) Lyon méd., 225, 649

Pettay, O., LeinikKi, P., Donner, M., and Lapinleimu, K. (1972) Arch. Dis. Childh., 47, 97

Platt, M. S. (1971) Clin. Pediat., 10, 513

Rajam, R. V., and Rangiah, P. N. (1954) Donovanosis, granuloma inguinale, granuloma venereum. Monograph Series No. 24, World Health Organisation, Geneva

Rasul, G. (1970) f. Pakistan med. Ass., 20, 54

RAWLS, W. E., GardnER, M. C., and KaUfMan, R. L. (1970) Amer. F. Obstet. Gynec., 107, 710

RhATIGAN, R. M., JiMENEZ, S., and ChOPSKIE, E. J. (1972) Sth. med. F., 65, 423

Richmond, S. J., Hilton, A. L., and ClaRKe, S. K. R (1972) Brit. F. vener. Dis., 48, 437

RODRIGUEZ, M., ORAGAKI, T., and RICHART, R. M. (1972) Obstet. and Gynec., 39, 292

RollIER, R. (1969) Lyon méd., 222, 953

Royston, I., and Aurelian, L. (1970) Amer. F. Epidem., 91, 531

SEBEK, V. (1972) Cs. Gynek., 37, 14

ShaAban, M. M., ShokeIr, A. A., Wasfy, I. A., and AL-Hussaini, M. K. (1972) f. Obstet. Gynaec. Brit. Cwlth, 79, 360

SHEPARD, M. C. (1956) f. Bact., 71, 362

Soldatova, V. M., Bashmakova, M. A., and Stepanova, G. N. (1972) Akush. $i$ Ginek., 48, No. 3, p. 61

Sood, N. N., and Madhaven, H. N. (1968) f. pediat. Ophthal., 5, 242

Stewart, D. B. (1964) Med. Clin. N. Amer., 48, 773

W ALTHER, H. (1973) Z. Hautkr., 48, 553

Waugh, M. A. (1972) Trans. St fohn's Hosp. derm. Soc., 58, 224

Weinstein, E. C., Hayashida, T., and Clark, P. Le M. (1966) f. Amer. Geriat. Soc., 14, 80

WENTWORTH, B. B., BONIN, P., HOLMES, K. K., GuTMAN, L., WIEsNER, P., and AleXXANDER, E. R. (1973) Hlth Lab. Sci., 10, 75

WHO (1973) World Health Statistics Annual 1970, vol. 1, Vital Statistics and Causes of Death. WHO, Geneva

WILLcox, R. R. (1968) Brit. med. F., 1, 610

- (1972) Brit. F. vener. Dis., 48, 163 (1974) Unpublished Report to WHO

WISE, G. J., WeINSTEIN, S., GoldBerg, P., and KozINN, P. J. (1973) f. Amer. med. Ass., 224, 1636

Young, R. L., Acosta, A. A., and Kaurman, R. H. (1973) Obstet. and Gynec., 41, 65 